\title{
Evaluation of optical properties of different restorative composite resins
}

\section{Raquel Pachaly ${ }^{1}$, Manuela Batistella Zasso², Mariah Bonilha Silveira ${ }^{3}$, Roselaine Terezinha Pozzobon ${ }^{4}$}

${ }^{1}$ Mestranda do Programa de Pós-Graduação em Ciências Odontológicas da Universidade Federal de Santa Maria - UFSM - Rio Grande do Sul - Brasil

\section{Resumo}

Devido à exigência estética, tem-se buscado materiais restauradores que se aproximem da aparência do dente natural. Para tal, é importante conhecer as propriedades ópticas tanto das estruturas dentais quanto dos materiais restauradores. Este estudo objetivou avaliar a translucidez/opacidade e fluorescência de 16 resinas compostas, na cor universal A2, selecionadas aleatoriamente, a partir das quais foram confeccionados corpos de prova, com $1 \mathrm{~mm}$ de espessura e $10 \mathrm{~mm}$ de diâmetro que foram submetidos a avaliação das propriedades ópticas, sendo classificados como alta, média e baixa translucidez/opacidade e fluorescência. Nos testes W de Kendall e ao teste de Friedman a $5 \%$ de significância, verificou-se que as resinas Opallis D, Four Season D, Concept E, Concept D e FillMagic apresentaram baixa translucidez. As resinas Opallis E, Charisma, Tetric Ceram, Four Season E, Natural Look, Z350 e Z250 apresentaram média translucidez/opacidade e as resinas Nova Charisma, Durafill e Supreme XT, alta translucidez. Para fluorescência, as resinas Charisma, Z350, Supreme XT e Z250 apresentaram baixa fluorescência. As de média fluorescência foram Opallis E, Opallis D, Nova Charisma, Durafill, Natural Look, TPH Spectrum, Tetric Ceram, Four Season E e Four Season D. Por fim, as resinas compostas Concept E, Concept D e Fill Magic apresentam alta fluorescência. A partir dos resultados, conclui-se que existem diferenças nos graus de translucidez/opacidade e fluorescência nas diferentes resinas compostas testadas, o que, possivelmente, está relacionado às variações na composição das mesmas.

Palavras-chave: Odontologia, Dentística, Materiais dentários, Estética.

\section{Abstract}

The esthetic demands of patients have encouraged the search for restorative materials increasingly similar to natural teeth. This requires knowledge on the optical properties of dental structures and restorative materials. This study comparatively evaluated the translucency/opacity and fluorescence of different brands of composite resins. Sixteen brands of composite resins shade A2 were randomly selected; specimens with $1 \mathrm{~mm}$ thickness and $10 \mathrm{~mm}$ diameter were fabricated with these resins and evaluated as to the optical properties, scored as high, medium and low translucency/ opacity and fluorescence. Statistical analysis by the Kendall W test and Friedman test at a significance level of $5 \%$ revealed that the resins Opallis D, Four Season D, Concept E, Concept D, and FillMagic presented low translucency. Conversely, the resins Opallis E, Charisma, Tetric Ceram, Four Season E, Natural Look, Z350, and Z250 exhibited medium translucency/opacity, and resins Nova Charisma, Durafill, and Supreme XT presented high translucency. With regard to fluorescence, the resins Charisma, Z350, Supreme XT, and Z250 present low fluorescence. Medium fluorescence was observed for the resins Opallis E, Opallis D, Nova Charisma, Durafill, Natural Look, TPH Spectrum, Tetric Ceram, Four Season E, and Four Season D. The composite resins Concept E, Concept D, and Fill Magic presented high fluorescence. Based on these results, it is concluded that there are differences in the degree of translucency/opacity and fluorescence of different composite resins, which are possibly related to variations in their composition.

Keywords: Dentistry, Restorative dentistry, Dental materials, Esthetics.
${ }^{2}$ Cirurgiã-Dentista, graduada na Universidade Federal de Santa Maria - UFSM - Rio Grande do Sul - Brasil

${ }^{3}$ Cirurgiã-Dentista, graduada na Universidade Federal de Santa Maria - UFSM - Rio Grande do Sul - Brasil

${ }^{4}$ Professora-associada da disciplina de Dentística do Departamento de Odontologia Restauradora da UFSM e Docente permanente do Programa de Pós-Graduação em Ciências Odontológicas da Universidade Federal de Santa Maria - Rio Grande do Sul - Brasil

Correspondence: Profa. Dra. Roselaine Terezinha Pozzobon Address: Av. Fernando Ferrari, 1070/301 - CEP 97050-800 Santa Maria - RS - Brasil

E-mail:rpozzobon@uol.com.br

\section{Introduction}

The esthetics of smile has been increasingly valued. According to Pinlkington (apud CHAIN; RODRIGUES; ANDRIANI, 2002), it has been defined as the science to copy or harmonize the professional work with nature, making it an imperceptible art (BARATIERI; MONTEIRO JÚNIOR; ANDRADA, 1995).

With the development of restorative and adhesive dentistry was possible the construction of esthetic restorations with characteristics more similar to natural teeth. For achievement of these perfect restorations, the dental professionals should have current information and skill to offer esthetic treatments, since this is one of the main reasons for search for treatment, which aims at promoting health and self-esteem, beyond to bring social and intellectual acceptance. To achieve the patient expectations is essential have the knowledge of the shape, texture and color of restorations, beyond the understanding the optical properties of dental tissues and inherent properties of esthetic restorative materials. (CHAIN; RODRIGUES; ANDRIANI, 2002; JARDIM et al., 2002; TERRY, 2002; FRANCO, 2007).

The optical properties of an esthetic material include translucency, opacity, fluorescence and opalescence. Translucency may be defined as the property of a substance that permits the passage of light but disperses the light so that objects cannot be seen through the material (POWERS, 2006). Opacity is the property of materials that does not allow the passage of light; i.e. opaque structures have higher intensity of light dispersion (CHAIN; RODRIGUES; ANDRIANI, 2002). Fluorescence is a type of photoluminescence, in which the ultraviolet radiant energy (UV) is absorbed by an object that later emits light energy within the visible spectrum. The natural fluorescence of dental tissues is an important component that should be reproduced in composite resin restorations; it assigns vitality and luminosity to restorations (CORREIA; OLIVEIRA; SILVA, 2005). Opalescence is assigned by opalizing agents, which are fine or extrafine particles in charge of light dispersion within the tooth structure. This dispersion varies according to the size and quantity of particles, which consequently influences the material refraction index; opalescence is an inherent optical phenomenon of enamel (CHAIN; RODRIGUES; ANDRIANI, 2002; VANINI; MANGANI, 2001). Since enamel contains hydroxyapatite crystals that are smaller than the visible light wavelength, shorter light wavelengths penetrating it suffer dispersion; this assigns the blue aspect of incisal areas without dentine superimposition. Conversely, dispersion hardly occurs in longer light wavelengths, which reach the palatal interface of the tooth and assign the orange aspect to the tooth. Therefore, the enamel acts as a filter that absorbs the blue colors and allows the passage of orange colors (WATANABE, 2005). 
The concepts for direct restorative esthetic materials are relatively recent. For this reason, there are still doubts during selection and purchase of the ideal material for fabrication of imperceptible esthetic restorations, able to satisfy both the professional and the patient. Therefore, this study aimed to investigate the optical properties of restorative composite resins, for evaluation of translucency, opacity and fluorescence of different brands of composite resins.

\section{Materials and Methods}

The present study was divided into two stages.

On the first stage, sixteen brands of composite resins were selected, shade A2, which were commercially available in Santa Maria, Rio Grande do Sul- Brazil, which constituted the study sample (Table 1).

Table 1. Composite resins evaluated

\begin{tabular}{|c|c|c|c|c|}
\hline $\begin{array}{l}\text { Composite } \\
\text { Resin }\end{array}$ & $\begin{array}{l}\text { Comercial } \\
\text { Name }\end{array}$ & Manufacturer & City - State - Country & Lot \\
\hline 1 & Opallis E & FGM & Joinville - SC - Brazil. & 131206 \\
\hline 2 & Opallis D & FGM & Joinville - SC - Brazil. & 020407 \\
\hline 3 & Charisma & $\begin{array}{l}\text { Heraeus } \\
\text { Kulzer }\end{array}$ & $\begin{array}{l}\text { Hanau - Hessen - } \\
\text { Germany }\end{array}$ & 010088 \\
\hline 4 & Nova Charisma & $\begin{array}{l}\text { Heraeus } \\
\text { Kulzer }\end{array}$ & $\begin{array}{c}\text { Hanau - Hessen - } \\
\text { Germany }\end{array}$ & 010211 \\
\hline 5 & Tetric Ceram & $\begin{array}{c}\text { Ivoclar } \\
\text { Vivadent }\end{array}$ & $\begin{array}{c}\text { New York City - New } \\
\text { York - USA }\end{array}$ & J16185 \\
\hline 6 & Four Seasons E & $\begin{array}{l}\text { Ivoclar } \\
\text { Vivadent }\end{array}$ & $\begin{array}{c}\text { New York City - New } \\
\text { York - USA }\end{array}$ & Н33733 \\
\hline 7 & Four Seasons D & $\begin{array}{l}\text { Ivoclar } \\
\text { Vivadent }\end{array}$ & $\begin{array}{c}\text { New York City - New } \\
\text { York - USA }\end{array}$ & H04546 \\
\hline 8 & Durafill & $\begin{array}{l}\text { Heraeus } \\
\text { Kulzer }\end{array}$ & $\begin{array}{c}\text { Hanau - Hessen - } \\
\text { Germany }\end{array}$ & 010204 \\
\hline 9 & Natural Look & DFL & $\begin{array}{c}\text { Rio de Janeiro - RJ - } \\
\text { Brazil }\end{array}$ & 06030447 \\
\hline 10 & TPH Spectrum & Dentsply & Petrópolis - RJ - Brazil & 22080 \\
\hline 11 & Concept E & Vigodent/SA & $\begin{array}{c}\text { Rio de Janeiro - RJ - } \\
\text { Brazil }\end{array}$ & 064/05 \\
\hline 12 & Concept D & Vigodent/SA & $\begin{array}{c}\text { Rio de Janeiro - RJ - } \\
\text { Brazil }\end{array}$ & 006/06 \\
\hline 13 & Fill Magic & Vigodent/SA & $\begin{array}{c}\text { Rio de Janeiro - RJ - } \\
\text { Brazil }\end{array}$ & $116 / 06$ \\
\hline 14 & Filtek Z350 & $3 \mathrm{M}$ & $\begin{array}{c}\text { Saint Paul - Minnesota } \\
\text { - USA }\end{array}$ & $6 \mathrm{EJ}$ \\
\hline 15 & $\begin{array}{c}\text { Filtek Supreme } \\
\text { XT }\end{array}$ & $3 \mathrm{M}$ & $\begin{array}{c}\text { Saint Paul - Minnesota } \\
\text { - USA }\end{array}$ & $5 B U$ \\
\hline 16 & Filtek Z250 & $3 \mathrm{M}$ & $\begin{array}{c}\text { Saint Paul - Minnesota } \\
\text { - USA }\end{array}$ & $5 \mathrm{JK}$ \\
\hline
\end{tabular}

On the second stage, tests were performed to evaluate the optical properties of translucency/opacity and fluorescence, by application of the following methods.

\section{Fabrication of specimens}

For fabrication of specimens employed in the present study, a disc-shaped acrylic matrix with $15 \mathrm{~mm}$ diameter, $1 \mathrm{~mm}$ thickness and $10 \mathrm{~mm}$ diameter round central perforation was fabricated, which was positioned on a glass plate for insertion of composite resin into the central perforation in a single increment, with aid of a Teflon spatula. A polyester strip and another glass plate were placed on the resin and approximately $2 \mathrm{~kg}$ of finger pressure was applied, which allowed better fit and overflow of excess material. The resin was lightcured by three 30-second periods; the first was performed with the glass plate on the specimen, the second was performed soon after removal of the glass plate, and the third was applied on the opposite side of the specimen. This was performed by utilization of a halogen light curing unit (Dabi Atlante) with energy of $400 \mathrm{~mW} / \mathrm{cm}^{2}$, previously tested by a radiometer.

\section{Storage of specimens}

After separation of matrices and specimens, these were identified so as to prevent identification of materials with their brands by the examiners. The specimens were then immersed in labeled individual flasks containing distilled water and placed in an oven at $37^{\circ} \mathrm{C}$ for seven days. After this period, tests were performed to evaluate the translucency and fluorescence.

Evaluation of translucency/opacity was performed by visual comparative analysis, which comprises placement of specimens with $50 \%$ of their area on black strips and $50 \%$ on white background. For visual analysis of translucency, four independent calibrated examiners employed the following criterion: numerical classification of specimens, from the specimen allowing lower visibility of the black strip to that allowing greater visibility, i.e. from the most opaque to the most translucent, classifying them into high, medium and low translucency. Analysis of fluorescence was performed on an image obtained with a digital photo camera in a completely dark environment, in which the specimens were exposed to artificial ultraviolent light from a compact fluorescent lamp (cool-white color 4200K/9W) and had their fluorescence emitted and recorded. Evaluation of images was performed by the same examiners, following the same methodology, i.e. they classified the specimens into high, medium and low fluorescence, according to the luminosity emitted by the material, compared to a natural anterior tooth.

Data were organized and statistically analyzed.

\section{Results}

For the data obtained, score 0 (zero) was assigned when fluorescence and translucency were scored as high, score 1 (one) when scored as medium, and 2 (two) when scored as low. Agreement of data was verified by the Kendall W test.

The mean scores obtained by specimens were compared by the non-parametric Friedman test; a multiple comparison test was applied when the Friedman test revealed significant differences. All tests were applied at a significance level of $5 \%$.

The Kendall W test revealed values of 0.872 for fluorescence and 0.925 for translucency, which revealed high agreement in scores assigned by the examiners.

The Friedman test revealed significant differences between the mean scores of specimens, for both fluorescence and translucency. 
On evaluation of translucency, $\mathrm{RC} 2, \mathrm{RC} 7, \mathrm{RC} 11, \mathrm{RC} 12$, and $\mathrm{RC} 13$ presented the lowest translucency and RC4, RC8, and $\mathrm{RC} 15$ exhibited the highest; the others had intermediate positions, as presented in Table 2 and Graph 1.

Table 2. Mean translucency results by application of the Friedman test, at a significance level of $5 \%$

\begin{tabular}{|c|c|c|c|}
\hline Material & $\mathrm{N}$ & Mean translucency & \\
\hline $\mathrm{RC} 2$ & 4 & 2.00 & a \\
\hline $\mathrm{RC7}$ & 4 & 2.00 & a \\
\hline $\mathrm{RC} 11$ & 4 & 2.00 & a \\
\hline $\mathrm{RC} 12$ & 4 & 2.00 & a \\
\hline $\mathrm{RC} 13$ & 4 & 2.00 & a \\
\hline RC5 & 4 & 1.00 & $a b$ \\
\hline RC9 & 4 & 1.00 & $a b$ \\
\hline $\mathrm{RC} 10$ & 4 & 1.00 & $a b$ \\
\hline $\mathrm{RC} 16$ & 4 & 1.00 & $a b$ \\
\hline $\mathrm{RC} 3$ & 4 & .75 & $a b$ \\
\hline $\mathrm{RC} 14$ & 4 & .75 & $a b$ \\
\hline $\mathrm{RC} 1$ & 4 & .25 & $a b$ \\
\hline $\mathrm{RC} 6$ & 4 & .25 & $a b$ \\
\hline $\mathrm{RC} 4$ & 4 & .00 & $\mathrm{~b}$ \\
\hline $\mathrm{RC} 8$ & 4 & .00 & $b$ \\
\hline $\mathrm{RC} 15$ & 4 & .00 & $b$ \\
\hline
\end{tabular}

*Same letters indicate mean values that are not significantly different.

\section{Mean translucency}

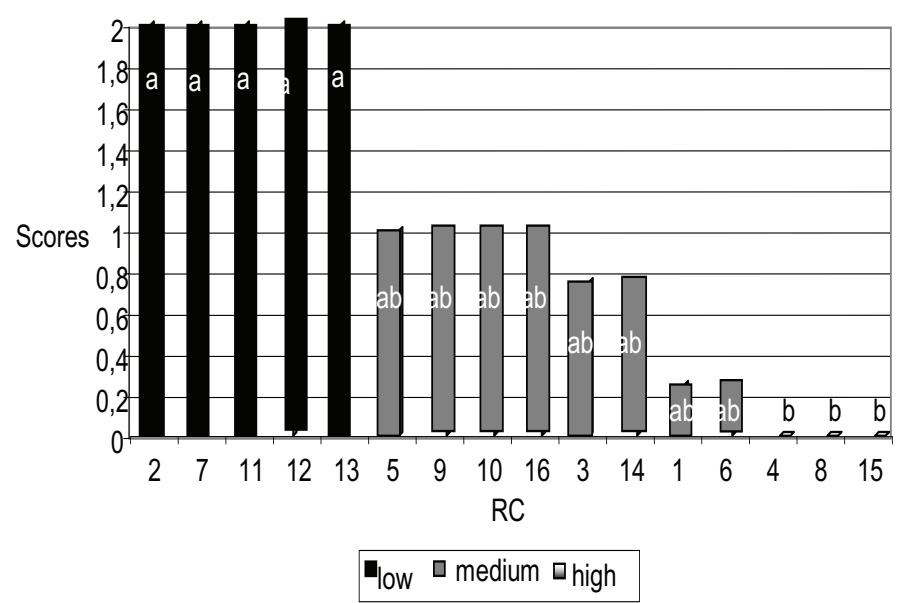

Graph 1. Graphic representation of mean translucency of composite resins evaluated

Concerning fluorescence, RC3, RC14, RC15, and RC16 exhibited the lowest fluorescence and presented statistically significant difference compared to RC11, RC12, and RC13, which presented the highest fluorescence. This is evidenced in Table 3 and Graph 2.
Table 3. Mean fluorescence results by application of the Friedman test, at a significance level of $5 \%$

\begin{tabular}{|c|c|c|c|}
\hline Material & $\mathrm{N}$ & Mean fluorescence & \\
\hline $\mathrm{RC} 3$ & 4 & 2.00 & a \\
\hline $\mathrm{RC} 14$ & 4 & 2.00 & a \\
\hline $\mathrm{RC} 15$ & 4 & 2.00 & a \\
\hline $\mathrm{RC} 16$ & 4 & 2.00 & a \\
\hline $\mathrm{RC} 1$ & 4 & 1.25 & $a b$ \\
\hline $\mathrm{RC} 2$ & 4 & 1.25 & $a b$ \\
\hline $\mathrm{RC7}$ & 4 & 1.25 & $a b$ \\
\hline $\mathrm{RC} 8$ & 4 & 1.25 & $a b$ \\
\hline $\mathrm{RC} 9$ & 4 & 1.25 & $a b$ \\
\hline $\mathrm{RC} 10$ & 4 & 1.25 & $a b$ \\
\hline $\mathrm{RC} 6$ & 4 & 1.00 & $a b$ \\
\hline $\mathrm{RC} 4$ & 4 & .75 & $a b$ \\
\hline $\mathrm{RC5}$ & 4 & .75 & $a b$ \\
\hline $\mathrm{RC} 11$ & 4 & .25 & $b$ \\
\hline $\mathrm{RC} 12$ & 4 & .25 & $\mathrm{~b}$ \\
\hline $\mathrm{RC} 13$ & 4 & .00 & $\mathrm{~b}$ \\
\hline
\end{tabular}

*Same letters indicate mean values that are not significantly different.

Mean fluorescence

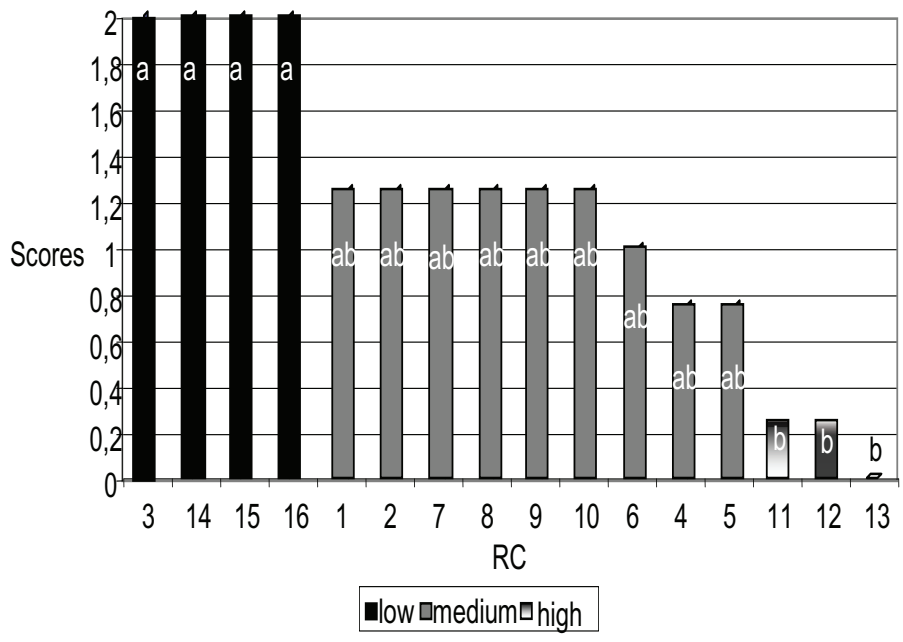

Graph 2. Graphic representation of mean fluorescence of composite resins evaluated

The non-parametric coefficient of correlation of Spearman was calculated to verify if there was correlation between translucency and fluorescence properties, since data were measured on an ordinal scale. The calculated value was significant at the $1 \%$ level ( $\mathrm{rs}=$ 0.400 ). The coefficient obtained indicated association between the two variables, i.e. the higher the value of one of them, the lower would be the other. Most RCs with high fluorescence tended to present low translucency. 


\section{Discussion}

Due to patients' demands, the search for esthetic restorations has increased in the last years. Consequently, a new era has been observed in Restorative Dentistry, due to the development of new esthetic materials and increased number of informed patients (HIRATA; AMPESSAN; LIU, 2001; VILLARROEL; HIRATA; SOUSA, 2005). Currently, professionals should not only recover the lost function of the tooth, but also achieve a beautiful outcome, according to the demands of society. This requires correct planning, accomplishment of restorations and precise utilization of the restorative material (BUSATO; HERNANDEZ; MACEDO, 2002).

The great challenge in Restorative Dentistry is to perform restorations similar to the tooth structure, since natural teeth are polychromatic structures, whose crown is performed by superimposition of enamel and dentine, two translucent tissues that play different and complementary roles in the expression of tooth shade (TERRY, 2002). The dentine presents low translucency and high saturation and is the main responsible for the basic hue and saturation of natural teeth. Enamel is significantly more translucent than dentine, attenuating its saturation and acting as an optic fiber able to transmit light to the underlying dentine (BEHLE, 2001a; 2001b; MELO; KANO; ARAÚJO JUNIOR, 2005a; 2005b)

Knowledge on the factors that influence the optica properties of both tooth structures and esthetic restorative materials is fundamental for achievement of esthetic excellence of direct composite resin restorations. Due to this high demand, the translucency and fluorescence were investigated.

Translucency is the transmission and diffusion of light through an object, i.e. it is the medium point between complete opacity and complete transparency. It allows similar aspect to both restorative material and natural teeth, and thus the achievement of excellent esthetic outcome (CORREIA; OLIVEIRA; SILVA, 2005; VILLARROEL; HIRATA; SOUSA, 2005; POWERS, 2006).

According to Magne and Belser (2002), the phenomenon of fluorescence may be created by UV rays of sunlight, which excite the photosensitivity of dentine after penetrating the enamel and reaching the dentine. This phenomenon is caused by dentine, which presents more intense fluorescence than enamel due to the presence of higher amount of organic pigments that are photosensitive to the UV spectrum (VILLARROEL et al., 2004).

Fluorescent materials and structures are able to absorb light from a wavelength and emit a different light wavelength in response. In natural teeth, fluorescence is characterized by the absorption of ultraviolent light, followed by emission of visible light at short wavelength. Since the emitted light is combined with reflected light, there is perceptible increase in the apparent luminosity of the structure (MELO; KANO; ARAÚJO JUNIOR, 2005a; 2005b).

Thus, based on results obtained by statistical analysis, it was possible to evaluate the translucency/opacity and fluorescence of different direct restorative composite resins.

It was observed that the resins Opallis D (FGM), Four Season D (Ivoclar Vivadent), Concept E (Vigodent), Concept D (Vigodent), and FillMagic (Vigodent) presented low translucency.

Conversely, the resins Opallis E (FGM), Charisma (Heraeus Kulzer), Tetric Ceram (Ivoclar Vivadent), Four Season E (Ivoclar Vivadent), Natural Look (DFL), TPH Spectrum (Dentsply), Z350 (3M/ESPE), and Z250 (3M/ESPE) exhibited medium translucency, and the resins Nova Charisma (Heraeus Kulzer), Durafill (Kulzer), and Supreme XT (3M/ESPE) were scored as high translucency.

These different translucencies in different resins may be assigned to variations in material composition. Lee (2007) concluded that the size of fillers and volume fractions should be controlled for the best color reproduction for dental resin composite, since the color of resin composites is highly correlated with scattering and absorption characteristics, which determine the translucency property.
According to Sturdevant et al. (apud VILLARROEL, HIRATA; SOUSA, 2005 ) the fillers would be responsible to produce light dispersion in its interior, producing the same phenomenon observed in enamel. Even when these particles present inherent transparency, opacity may be produced by dispersed light, which reaches maximum values when the size of particles have the same dimension as the visible light wavelength. The degree of translucency is influenced by the material composition; thus, the translucency of microparticles might be related to the size of fillers, which allow greater passage of light (JARDIM, 2002; VILLARROEL; HIRATA; SOUSA, 2005).

Analysis of fluorescence properties revealed that the resins Charisma (Heraeus Kulzer), Z350 (3M/ESPE), Supreme XT (3M/ ESPE), and Z250 (3M/ESPE) present low fluorescence. This partly agrees with the report of Villarroel et al. (2004), who investigated the fluorescence of resin Charisma.

Composite resins presenting medium fluorescence were Opallis E (FGM), Opallis D (FGM), Nova Charisma (Heraeus Kulzer), Durafill (Heraeus Kulzer), Natural Look (DFL), TPH Spectrum (Dentsply), Tetric Ceram (Ivoclar Vivadent), Four Season E (Ivoclar Vivadent), and Four Season D (Ivoclar Vivadent). Similar results were observed by Villarroel et al. (2004) analyzing the resins TPH Spectrum and Tetric Ceram.

Conversely, the composite resins Concept E (Vigodent), Concept D (Vigodent) and Fill Magic (Vigodent) presented high fluorescence. This was also demonstrated by Villarroel et al. (2004) for the resins Concept $E$ (Vigodent) and Concept D (Vigodent).

The basic components of restorative materials do not present fluorescence; however, this quality is reached by aggregation of higher or smaller amount of fluorescent components, like rare earth oxides which may assign high, medium or low fluorescence to the resin (VILLARROEL et al., 2004; UO et al., 2005).

The present results revealed a relationship between the composition of composite resins and their optical properties, as well as correlation between the properties of translucency and fluorescence. However, it is difficult to precisely establish this relationship, since both the scientific literature and technical information of materials do not present details on the composition; the manufacturers claim that such information constitutes industrial secret. Thus, the best parameters available so far are comparative studies between different materials and those comparison natural teeth and restorative materials.

\section{Conclusion}

Considering the present results, it was concluded that the composite resins evaluated presented different degrees of translucency/opacity and fluorescence. Possibly, these differences are related to variations in their composition, which may not be clearly demonstrated in the technical information provided to professionals by the manufacturers. The information presented in this study influence the clinical practice, since restorations with esthetic involvement depend on correct selection of the restorative material, which demands knowledge on the optical properties of composite resins. 


\section{References}

BARATIERI, L. N. et al. Estética: Restaurações Adesivas Diretas em Dentes Anteriores Fraturados. São Paulo: Quintessence, 1995.

BEHLE, C. Shade Selection Techniques: Part One-tools for Effective Communication. Pract. Proced. Aesthet. Dent., Mahwah, v. 13, n. 7, p. 536, Sept. 2001a.

Shade Selection Techniques: Part Two-dimensions of Color. Pract. Proced. Aesthet. Dent., Mahwah, v. 13, n. 8, p. 652-654, Oct. 2001b.

BUSATO, A. L. S.; HERNANDEZ, P. A. G.; MACEDO, R. P. Dentística: Restaurações Estéticas. São Paulo: Artes Médicas, 2002.

CHAIN, M. C.; RODRIGUES, C. C.; ANDRIANI, O. Estética: Dominando os Desejos e Controlando as Expectativas. In: Cardoso, R. J. A.; Gonçalvez, E. A. N. Odontologia Estética. São Paulo: Artes Médicas, Cap. 4, p. 43-78, 2002.

CORREIA, A.; OLIVEIRA, M. A.; SILVA, M. J. Conceitos de Estratificação nas Restaurações de Dentes Anteriores com Resinas Compostas. Rev. Port. Estomatol. Med. Dent. Cir. Maxilofac., Lisboa, v. 46, n. 3, p. 171-178, 2005.

FRANCO, E. B. et al. Reproducing the Natural Aspects of Dental Tissues with Resin Composites in Proximoincisal Restorations. Quintessence Int., Belin, v. 38, n. 6, p. 505-510, June 2007.

HIRATA, R.; AMPESSAN, R. L.; LIU, J. Reconstrução de Dentes Anteriores com Resinas Compostas: uma Seqüência de Escolha e Aplicação de Resinas. JBC J. Bras. Clín. Estét. Odontol., Curitiba, v. 5, n. 25, p. 15-25, jan./fev. 2001.

JARDIM, P. S. et al. Análise Comparativa da Translucidez do Esmalte e de Diferentes Resinas Compostas Microparticuladas. Ciênc. Odontol. Bras., São José dos Campos, v. 5, n. 3, p. 18-23, set./dez. 2002.

LEE, Y. K. Influence of Scattering/Absorption Characteristics on the Color of Resin Composites. Dent. Mater., Copenhagen, v. 23, n. 1, p. 124-131, Jan. 2007.

MAGNE, P.; BELSER, U. Estética Oral Natural. In: Magne, P. Restaurações Adesivas de Porcelana na Dentição Anterior. uma Abordagem Biomimética. Rio de Janeiro: Quintessence, p. 86-87, 2002.

MELO, T. S.; KANO, P.; ARAÚJO JUNIOR, E. M. A. Avaliação e Reprodução Cromática em Odontologia Restauradora. Parte I: o Mundo das Cores. Int. J. Braz. Dent., São José, v. 1, n. 2, p. 96-104, abr./jun. 2005.

MELO, T. S.; KANO, P.; ARAÚJO JUNIOR, E. M. A. Avaliação e Reprodução Cromática em Odontologia Restauradora. Parte II: a Dinâmica da Luz nos Dentes Naturais. Int. J. Braz. Dent., São José, v. 1, n. 4, p. 295-303, out./dez. 2005.

POWERS, J. M.; SAKAGUCHI, N. J. (Ed.). Craig's Restorative Dental Materials. 12th ed. St. Louis: Mosby Elsevier, p. 35-42, 2006.

TERRY, D. A. Anatomical Form Defines Color: Function, Form, and Aesthetics. Pract. Proced. Aesthet. Dent., Mahwah, v. 14, n. 1, p. 59-67, Jan./Feb. 2002.
UO, M. et al. Rare Earth Oxide-containing Fluorescent Glass Filler for Composite Resin. Dent. Mat. J., Tokyo, v. 24, n. 1, p. 49-52, Mar. 2005.

VANINI, L.; MANGANI, F. M. Determination and Communication of Color Using the Five Color Dimensions of Teeth. Pract. Proced. Aesthet. Dent., Mahwah, v. 13, n. 1, p. 19-26, Jan./Feb. 2001.

VILLARROEL, M. Fluorescência: uma Contribuição na Vitalidade Natural do Dente Humano. Rev. Ibero-Am. Odontol. Estet. Dent., Curitiba, v. 3, n. 12, p. 397-406, 2004.

VILLARROEL, M.; HIRATA, R.; SOUSA, A. M. Avaliação Comparativa da Translucidez do Esmalte Dentário e de Resinas Compostas para Esmalte. Rev. Dent. Press de Estét., Maringá, v. 2, n. 3, p. 2234, jul./set. 2005.

WATANABE, M. U. Resinas Compostas: o Estado da Arte. Rev. Dent. Press Estét., Maringá, v. 2, n. 2, p. 44-56, abr./jun. 2005. 